\title{
New technologies opposing urban sustainability
}

\author{
A. Gospodini \\ University of Thessaly, Volos, Greece
}

\begin{abstract}
This paper is concerned with the impacts of new technologies on urban sustainability. First, it briefly presents those new technological developments affecting urban life of individuals. Then, it focuses on new spatial phenomena which are encouraged by new technologies and opposing urban sustainability: (a) urban sprawl, exurban new centralities and the 'dispersed city', and (b) the socio-demographic restructuring and diminishing of inner city areas. It finally discusses green architecture and energy-save buildings which nowadays are feasible by new technological developments, and in this sense, they may moderate the negative impacts of new technologies on cities.

Keywords: urban sustainability, new technologies, spatial impacts, dispersed city, socio-demographic restructuring of inner city areas, green architecture.
\end{abstract}

\section{New technologies affecting urban life}

In the last two decades or so, a series of new technological developments has strongly affected everyday life of individuals in developed regions of the global: First, new developments in ICT's, multimedia and telecommunications provide excessive information to individuals generating a growing flow of events in time, or a kind of 'acceleration of history', and giving rise to information societies (see [1-9]). Second, the development and increasing use of mobile telecommunications (mobile cells, mobile internet connections), as combined with the development of high-speed transportation means and infrastructure, such as high-speed trains and closed high speed motorways in urban, suburban, and regional networks, offer individuals the possibility to make use of almost all office facilities in terms of communication and work, while travelling. This has resulted in high mobility of individuals on all territorial scales - metropolitan, regional, continental, and the rise of the phenomenon of 'time-space 
compression' characterising the era of new modernity. Third, internet and its products, exhibit a rapid increase of users worldwide (see Figs. 1 and 2, Table 1). This offers the potential of distance participation - or electronic access - of individuals in various social activities such as education, work, shopping, banking, recreation, leisure, tourism etc.

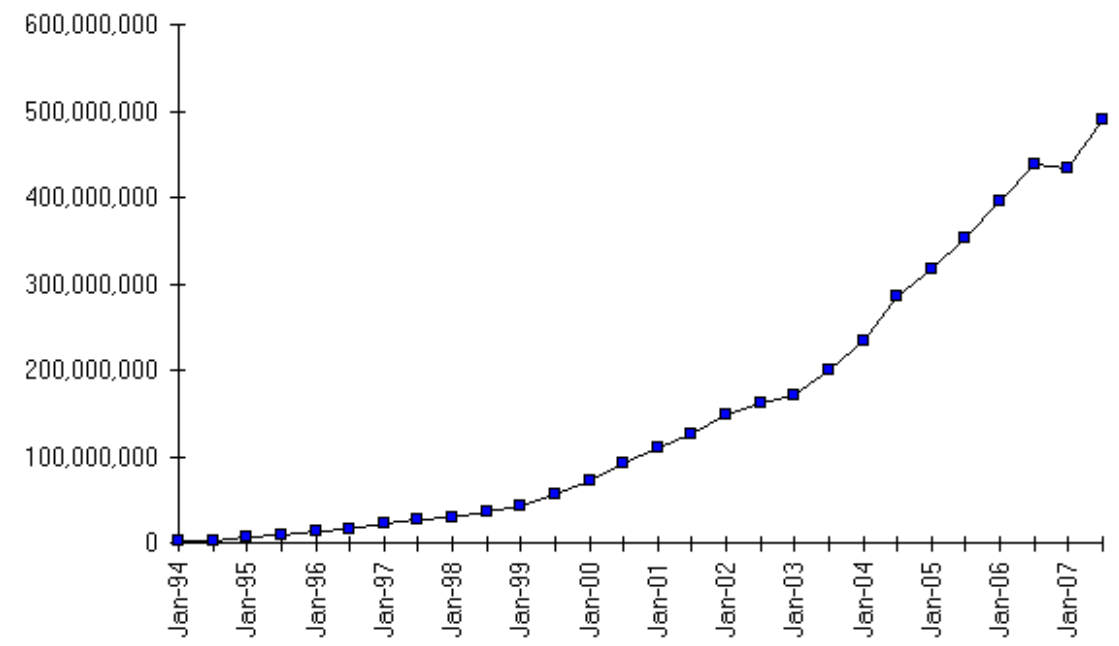

Figure 1: The rapid increase of internet users 1994-2007 [source: http://www.isc.org].

Table 1: World internet usage and population statistics; [data source: http://www.isc.org].

\begin{tabular}{|l|c|r|r|r|r|r|}
\hline World Regions & $\begin{array}{c}\text { estimated } \\
\text { population } \\
\text { in 2008 }\end{array}$ & $\begin{array}{c}\text { proportion } \\
\text { in world } \\
\text { population } \\
\%\end{array}$ & $\begin{array}{c}\text { internet users } \\
\text { (March 2008) }\end{array}$ & $\begin{array}{c}\text { population } \\
\text { penetration } \\
\%\end{array}$ & $\begin{array}{c}\text { world } \\
\text { share } \\
\%\end{array}$ & $\begin{array}{c}\text { usage } \\
\text { growth } \\
(\%) \\
(2000- \\
2008)\end{array}$ \\
\hline Africa & $955,206,348$ & $14.3 \%$ & $51,022,400$ & $5.3 \%$ & $\begin{array}{r}3.6 \\
\%\end{array}$ & $\begin{array}{r}1030.2 \\
\%\end{array}$ \\
\hline Asia & $3,776,181,949$ & $56.6 \%$ & $529,701,704$ & $14.0 \%$ & $\begin{array}{r}37.6 \\
\%\end{array}$ & $\begin{array}{r}363.4 \\
\%\end{array}$ \\
\hline Europe & $800,401,065$ & $12.0 \%$ & $382,005,271$ & $47.7 \%$ & $\begin{array}{r}27.1 \\
\%\end{array}$ & $\begin{array}{r}263.5 \\
\%\end{array}$ \\
\hline Middle East & $197,090,443$ & $3.0 \%$ & $41,939,200$ & $21.3 \%$ & $\begin{array}{r}3.0 \\
\%\end{array}$ & $\begin{array}{r}1176.8 \\
\%\end{array}$ \\
\hline N. America & $337,167,248$ & $5.1 \%$ & $246,402,574$ & $73.1 \%$ & $\begin{array}{r}17.5 \\
\%\end{array}$ & $\begin{array}{r}127.9 \\
\%\end{array}$ \\
\hline $\begin{array}{l}\text { Latin America \& } \\
\text { Caribbean }\end{array}$ & $576,091,673$ & $8.6 \%$ & $137,300,309$ & $23.8 \%$ & $\begin{array}{r}9.8 \\
\%\end{array}$ & $\begin{array}{r}659.9 \\
\%\end{array}$ \\
\hline Oceania/Australia & $33,981,562$ & $0.5 \%$ & $19,353,462$ & $57.0 \%$ & $\begin{array}{r}1.4 \\
\%\end{array}$ & $\begin{array}{r}154.0 \\
\%\end{array}$ \\
\hline WORLD TOTAL & $6,676,120,288$ & $100.0 \%$ & $1,407,724,920$ & $21.1 \%$ & $\begin{array}{r}100.0 \\
\%\end{array}$ & $\begin{array}{r}290.0 \\
\%\end{array}$ \\
\hline
\end{tabular}




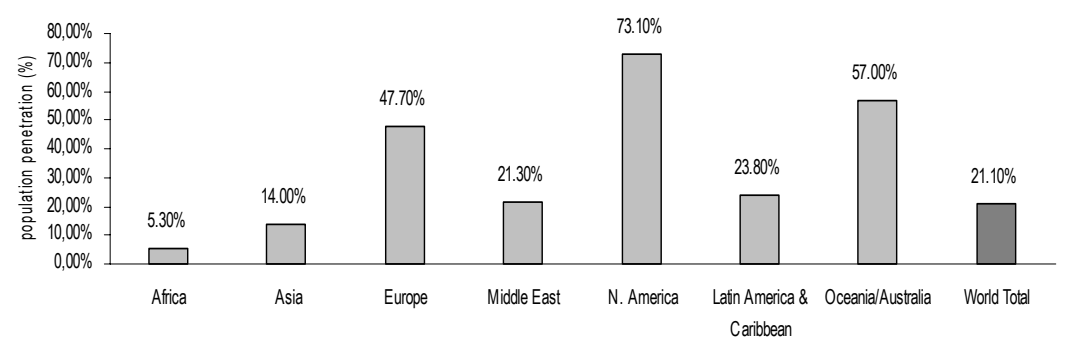

Figure 2: $\quad$ The increasing use of the internet. Population penetration graph.

These new modes of communication and social participation (e.g., teleeducation, tele-working, tele-shopping, tele-banking, etc) tend to blur the limits among social activities which in the past were well distinguished in terms of both time and space. Nowadays, by means of internet products and facilities like email, on line access, teleconference, etc, social activities such as work, education, creativity and leisure may simultaneously occur in the same space. Such spaces are neither home, nor office; they have no clear functional identity; and therefore, they tend to represent 'non-places' ('non-lieu') to use a term introduced by Mark Augé [10] as early as 1992.

\section{New technologies transforming cities and opposing urban sustainability}

Regarding urban history, it is widely accepted that the structure of societies and everyday life of individuals have always been reflected in space, thereby, shaping cities and urban settlements (see for instance [11]). The major changes in everyday life, as caused by the development and excessive use of new technologies in ICT's, multimedia and telecommunications, have already strong impacts on the spatial structure, form and landscape of cities:

The new potential of high mobility of individuals, as encouraged by highspeed transportation networks and new technologies in telecommunications, encourages urban sprawl. Urban fringe has always been suffering from pressures by urban economic activities gradually expanding into it as well as by various forms of suburbanisation. The 'compact-city' type of urban space had first been challenged already in the second half of the $19^{\text {th }}$ century and early $20^{\text {th }}$ century, when a first wave of suburbanisation took place in the form of garden cities and picturesque suburbs, developed around large European and North American cities as a result of the industrial revolutions, the increasing population densities of cities, and the degradation of natural environment. During the post-war decades - '50s, ' $60 \mathrm{~s}$ and '70s - the 'compact city' was challenged again by a second big wave of urban expansion and suburbanisation in the form of new residential districts and new towns, developed to absorb the demographic growth of metropolitan regions caused by high concentration of economic activities there. In the post-industrial era, despite increasing environmental consciousness 
about sustainable development and the disadvantages of urban sprawl in terms of land and energy consumption, urban sprawl has been continuous and intensified. And to crown all this, in the last decade or so, urban sprawl was accompanied by a shift in the patterns of development:

First, residential expansion in urban fringe belt has changed from patterns of spatially organised and master-planned settlements (e.g. new residential areas, new suburbs, new towns), as experienced in the past, to a pattern of unplanned scattered development that consists of dotted small housing schemes privately master-planned, or/and detached houses. There are plenty such examples in metropolitan regions. For instance, the area of Kitchener, Waterloo, Canada is a typical case which has well been analysed and documented [see 12].

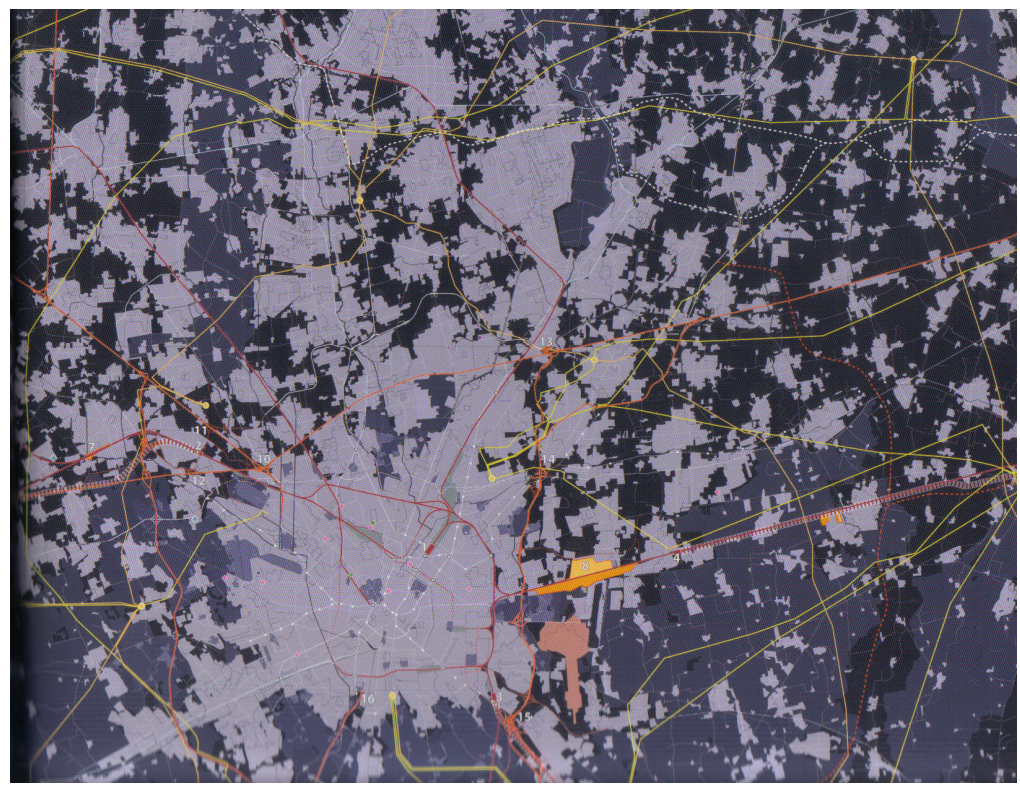

Figure 3: Urban sprawl in Milan's metropolitan area: Scattered development or/and linear development along main road arteries. [Source: Giovana Fossa (2006), An Atlas for Milan. Renewing the Urban Contexts of Infrastructure nodes, Milano: Skira Editore]

Second, decentralisation of urban economic activities such as commerce, services, culture, etc., has also shifted from the well-known pattern of peripheral or neighbourhood centres to (a) a pattern of scattered or/and linear development along peripheral motorways crossing urban fringe belts. For instance, as described in the case of Milan's fringe belt (see Figs. 2 and 3), there are "big commercial centres - the non-places of the hinterland (my italics)....Much of this development is linked to arterial routes and key transport - almost always car-based - links, forming spider-like settlements (my italics) radiating out from and into the old city, or around totally new, nodal, commercial and productive centres" ( [13]: 21). 


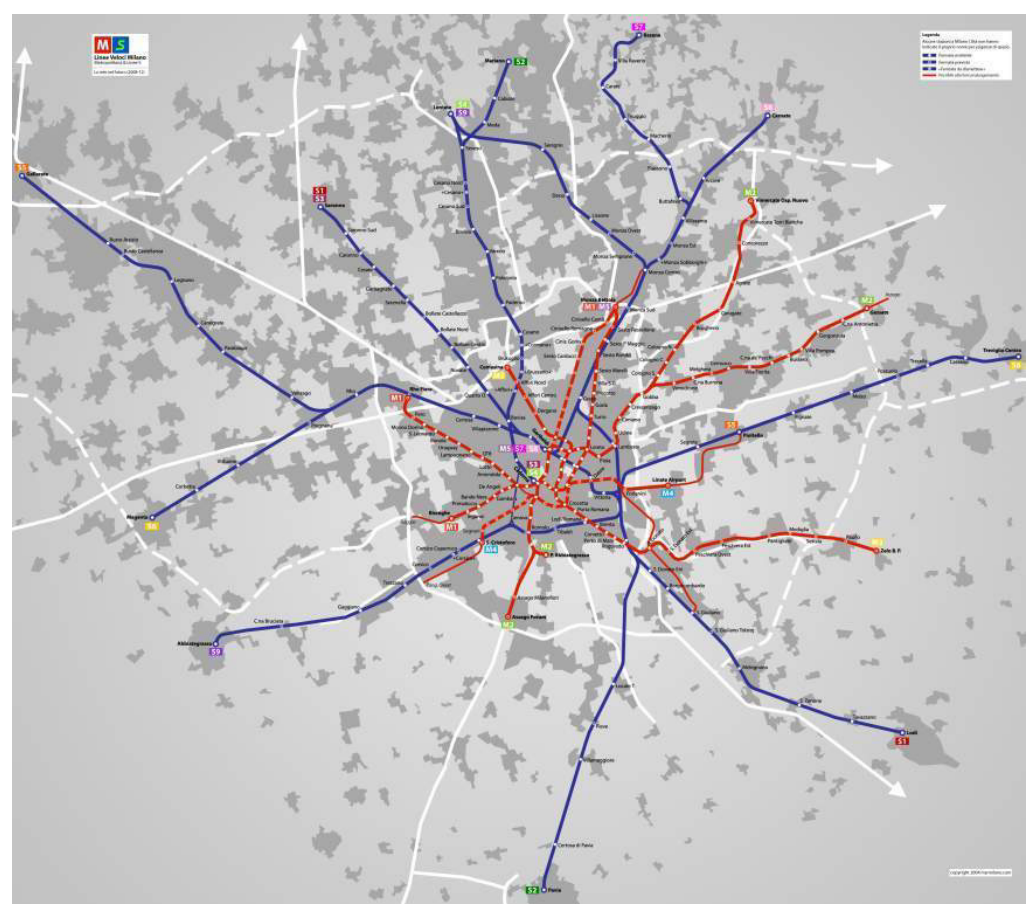

Figure 4: The metropolitan area of Milan. Scattered development or/and linear development along train network. [Source: Giovana Fossa (2006), An Atlas for Milan. Renewing the Urban Contexts of Infrastructure nodes, Milano: Skira Editore]

Another ground-breaking aspect is that some of urban economic activities developing in urban fringe belts such as large shopping centres, business parks, theme and amusement parks, sports centres, hospitals and others - often have reference not only to the adjacent outer city areas, but indeed to the city and the metropolitan area as a whole, while in some cases, they are even of national importance.

In terms of landscape, the building schemes accommodating shopping centres, business parks, theme parks, hospitals and colleges located in urban fringes, represent fragments of a 'city-centre' that are lacking an immediately adjacent residential periphery and being dispersed in the countryside. In this respect, one may understand them as city-centre episodes dispersed in the countryside. Such 'new centralities' are radically changing exurban space towards a landscape of diffused urbanity [14]. As described in the case of Milan, one "can now pass (i.e., by car or train) the whole Milanese region without ever losing sight of an urban landscape" ([13]: 11). This new exurban landscape exhibiting new centralities and housing dispersal involves not only metropolitan cities and large cities in the economic core of Europe and North America but also large cities in the expanding new core and the periphery - economic and 


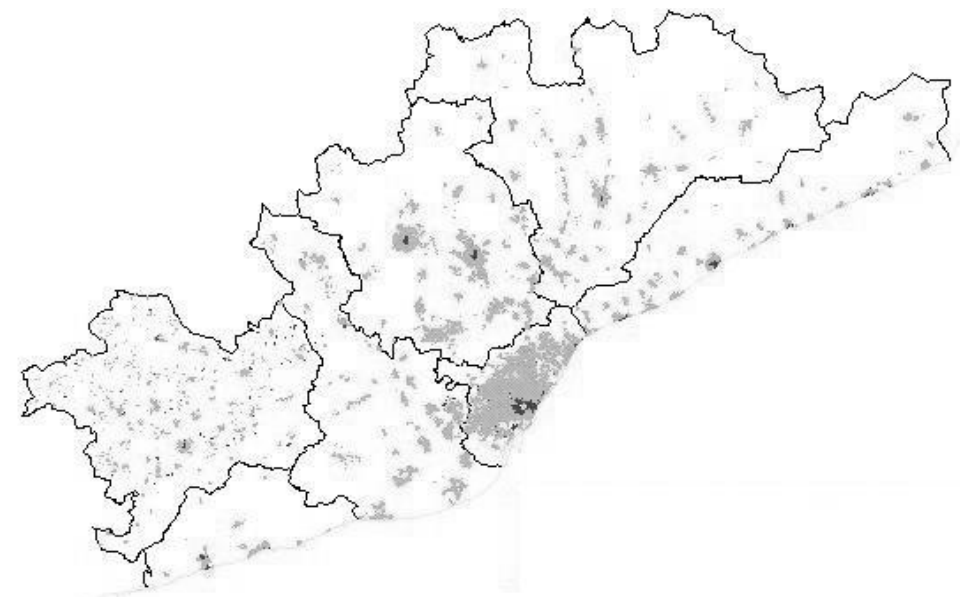

Figure 5: The metropolitan area of Barcelona, 1957. The image of a compact city with suburbs and villages. [Source: Borjia, J., with Zaida, M., (2001), L’ ESPAI PUBLIC: CIUTAT I CIUTADANIA, Barcelona: Diputacio de Barcelona]

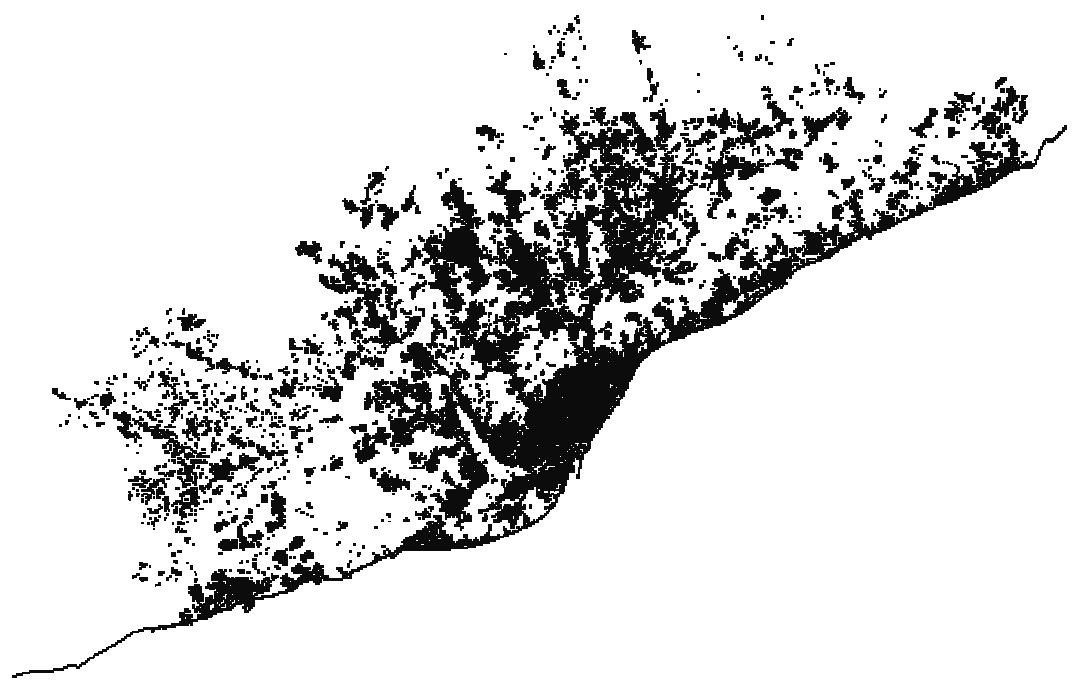

Figure 6: The metropolitan area of Barcelona metropolitan area, 1992. The image of a dispersed city and diffused urbanity. [Source: Borjia, J., with Zaida, M., (2001), L' ESPAI PUBLIC: CIUTAT I CIUTADANIA, Barcelona: Diputacio de Barcelona]

geographical - of Europe. In the last fifteen years, many cities in Spain, south France, Italy and Greece that used to be typical examples of the traditional 
Mediterranean compact-city type, have been witnessing what was until recently an Anglo-Saxon urban tradition - a dispersed low density development of detached and semi-detached single-family houses in fringe belts, and especially in the edges of motorways and orbital ring roads. In the case of Barcelona (see Figs. 4 and 5), in the period 1985-2000, the volume of newly built single family houses dispersedly located outside a planned settlement in the urban fringe represents more than $40 \%$ of the total volume in the case of inner fringes and more than $70 \%$ of the total volume in the case of outer fringes [14].

The landscape of Mediterranean cities is changing since "a new landscape appears and reveals itself as composed, designed and structured as a discontinuous sequence of physical elements: the semi-detached houses themselves, the roundabouts for the distribution of domestic traffic, or the medium and large shopping malls" ([15]: 382). The situation is similar in Greece, especially in the metropolitan regions of Athens and Thessaloniki. As far as residential development is concerned, inner and outer fringe belts are increasingly covered by detached and semi-detached single family houses, standing alone or being composed in small complexes of three to twenty maisonettes privately master-planned and dispersed in the countryside. Out-oftown shopping and entertainment malls are also present close to motorway junctions and orbital peripheral roads in urban fringes; they usually accommodate retail stores, multiplex cinemas, cafes, restaurants, public open spaces and amusement parks (see [14]).

As a consequence of exurban new centralities and housing dispersal encouraged by new technologies, city centres and inner city areas are often subjects of major changes:

(a) Part of economic activities, which have traditionally been located in city centres, like retail and services, now move out in exurban centres. Thus, city centres often exhibit a surplus of space vacancies and an atmosphere of deterioration;

(b) Space vacancies in city centres, as generated by the relocation of retail and services, are often re-occupied by cultural and entertainment activities, therefore endowing the heart of the city with a symbolic rather than productive character;

(c) Turning to housing, the potential of middle classes to move out of inner city and settle in urban fringe, as encouraged by high-speed transportation, telecommunications and electronic access to social activities and urban facilities, shifts the social character of inner city and creates a kind of social zoning: Central residential areas show a population decrease; For instance in Athens, this is well documented in Fig. 6. Simultaneously, they lose their social character becoming more and more exclusive places for low income families, economic immigrants and single families.

It may be argued that although processes of urban renewal and regeneration in the ' 80 s and early ' 90 s had a positive impact on inner city residential areas and urban sustainability, gentrification trends and processes are now being challenged by a mass wave of residential and economic decentralisation rooted and encouraged by new technologies. 

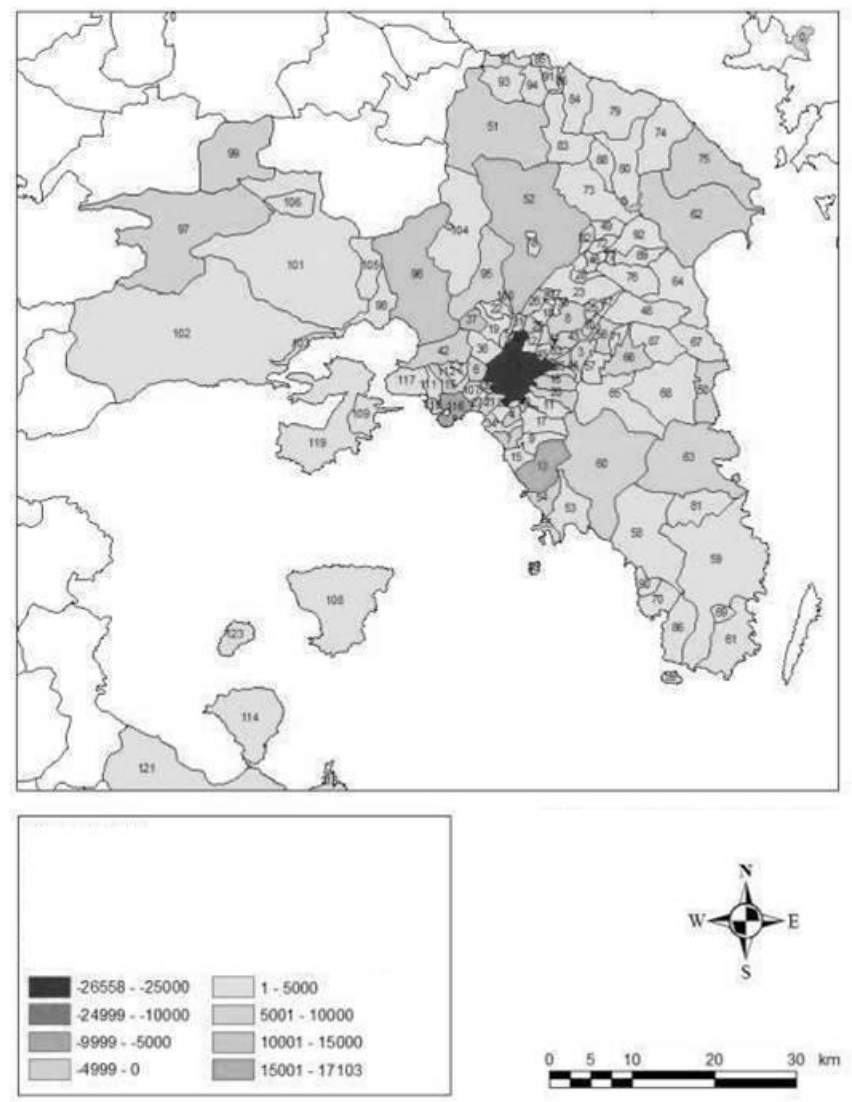

Figure 7: Athens' metropolitan area, Attica, Greece: Demographic changes 1991-2001. Peripheral urban areas coloured in light grey are characterised by growth of population while the historical centre and central residential areas coloured in black and dark grey exhibit a decrease of population. [Source: National Statistics Service of Greece]

\section{As an epilogue - New construction technologies supporting green architecture and urban sustainability}

Beyond the above negative impacts of new technologies on urban sustainability, the rising movement of Green architecture, or green design (see [15-20] and also Figs. 7 and 8) is largely rooted in the new technological developments and the new construction techniques that may minimize harmful effects of built fabric on human health and the natural environment.

The "green" design schemes attempt to safeguard air, water, and earth by choosing eco-friendly building materials and construction practices. They usually 
have many of the following virtues: green spaces for maximizing the natural cooling of buildings and the quality of air; passive solar energy; ventilation systems designed for efficient heating and cooling; alternate power sources such as solar power or wind power; energy-efficient lighting and appliances, watersaving plumbing fixtures; non-synthetic, non-toxic materials locally-obtained; responsibly-harvested woods; use of recycled architectural salvage.
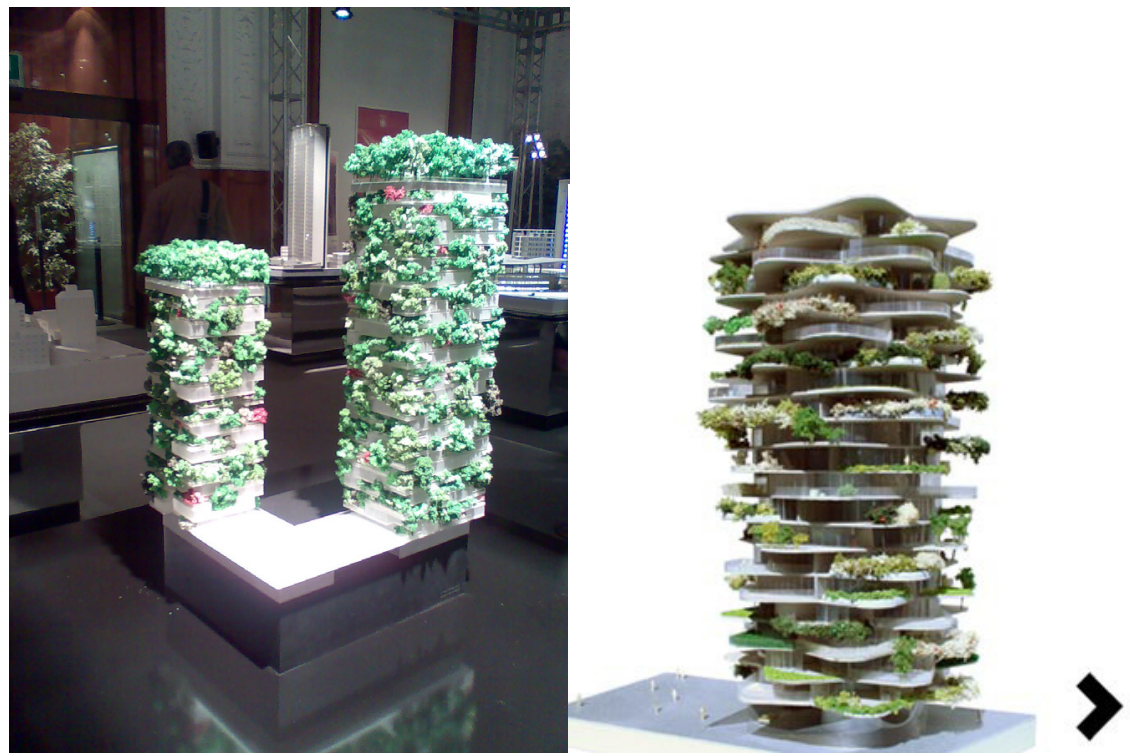

Figure 8: $\quad$ (left) Milan's new projects: Residential Towers, Nuovo Portello. [source: author's photo from the exhibition 'Milano la citta che sale’ by Municipality of Milan, 15 Feb. - 10 Apr. 2008]. Fig. 8 (right) The 'Urban Cactus' scheme by UCX Architects, Ben Huygen and Jasper Jaegers. [Source: http://cubeme.com/blog/2006/11/09/urban-cactus-high-rise]

The techniques used to achieve most of the above features are indeed products of new technologies. Thus, it may be said that they counteract and compensate for negative effects of new technologies opposing urban sustainability, such as urban sprawl, the dispersed city and the sociodemographic diminishing of historical centres and inner city areas.

\section{References}

[1] Castells, M. (1991) The Informational City: Information Technology, Economic Restructuring, and the Urban-Regional Process, Oxford and Cambridge MA: Blackwell.

[2] Castells, M. (1993) European Cities, the Informational Society, and the global Economy, in Journal of Economic and Social Geography, Ixxxiv, 4. 
[3] Castells, M. (1998) The Rise of the Network Society, 3 vol., Malden MA: Blackwell.

[4] Castells, M. (2001) The Internet Galaxy. Reflections on the Internet, Business and Society, Oxford: Oxford University Press.

[5] Castells, M., Fernandez-Ardevol, M., Linchuan Qui, J., Sey, A. (2006) Mobile Communication and Society: A global perspective, Cambridge MA: The MIT Press.

[6] Young, J. E. (1993) Global Networks - Computers in a Sustainable Society, Washington DC: Worldwatch Paper 115.

[7] Rheingold, H. (1994) The Virtual Community, London: Secker and Warburg.

[8] Graham S. and Marvin, S. (1996) Telecommunications and the City: Electronic Spaces, Urban Places, London: Routledge.

[9] Mitchell, W. (1995) City of Bits: Space, Place, and the infobahn, Cambridge MA: MIT Press.

[10] Augé, M. (1992) Non-Lieux. Introduction á une anthropologie de la surmodernité, Paris: Seuil.

[11] Rykwert, J. (1976) The Idea of a Town, London: Faber and Faber.

[12] Fillion, P., Bunting, T., Warriner, K. (1999) 'The Entrenchment of Urban Dispersion: Residential Preferences and location Patterns in the Dispersed city', Urban Studies 36(8): 1317-1347.

[13] Foot, J. (2000) 'The urban periphery, myth and reality. Milan 1950-2000', City 4(1): 7-26.

[14] Gospodini, A. (2006) 'Portraying, Classifying and Understanding the emerging landscapes in the Postmodern city', in Cities 23(5): 311-331.

[15] Munoz, F. (2003) 'Lock living: Urban sprawl in Mediterranean cities', Cities 20(6): 381-385.

[16] Cole, R. J. and Lorch, R. (eds) (2003) Buildings, culture and environment: informing local and global practices, Oxford, UK; Malden, MA: Blackwell Publications.

[17] Kwok, A. G. and Grondzik, W. T. (2007) The green studio handbook : environmental strategies for schematic design, Oxford; Burlington, MA : Architectural Press.

[18] Mendler, S., Odell, W., Lazarus, M.A. (2006) The HOK guidebook to sustainable design, Hoboken, N.J: Wiley Publications.

[19] Williams, D. E. (2007) Sustainable design: ecology, architecture, and planning, Hoboken: Wiley Publications.

[20] Chan Yenna (2007) Sustainable environments, Gloucester, MA: Rockport Publications. 